\title{
Child Nurture and Learning Assistance for Children in The Family During the Covid -19 Pandemic
}

\author{
Puji Yanti Fauziah $^{\circledR}{ }^{\bowtie}$, Rita Eka Izzaty ${ }^{2}$, Erma Kusumawardani ${ }^{1}$ \\ Pendidikan Luar Sekolah, Universitas Negeri Yogyakarta, Indonesia(1) \\ Pendidikan Psikologi, Universitas Negeri Yogyakarta, Indonesia(2) \\ DOI: $10.31004 /$ obsesi.v6i3.1809
}

\begin{abstract}
This study aims to find out the problems faced by child nurture and learning assistance for children in the family during the covid -19 pandemic. This research is a descriptive qualitative study with a survey method. This research was conducted in Yogyakarta Province. The respondents of this study were parents, totaling 78 people.This study used a closed questionnaire. The results of the study are that the Covid 19 pandemic has made parents experience various obstacles related to parenting and assisting children in learning, ranging from the inability of parents to explain school material, disciplining children, spending too much time with gadgets and technical obstacles faced by $50 \%$ of families. These technical constraints are related to signal, wifi, quota and the ability to own gadgets. So that in providing assistance such as quotas, it would be better if support was also given to students who do not have gadgets and assistance for areas that are still having problems with signals because there are no transmitters.
\end{abstract}

Keywords: child nurtute; learning assistance; covid-19 pandemic, parents.

\begin{abstract}
Penelitian bertujuan untuk mengetahui permasalahan yang dihadapi orangtua dalam melakukan pengasuhan dan pendampingan belajar anak selama masa pandemi Covid 19. Penelitian ini adalah penelitian kualitatif deskriptif dengan metode survey. Penelitian ini dilakukan di Provinsi Yogyakarta. Responden penelitian ini adalah orang tua yang berjumlah 78 orang. Penelitian ini menggunakan angket tertutup. Hasil penelitian adalah pandemi Covid 19 membuat orangtua mengalami berbagai kendala terkait dengan pengasuhan dan pendampingan anak dalam belajar, mulai dari ketidakmampuan orangtua dalam menjelaskan materi sekolah, mendisiplinkan anak, terlalu banyak menghabiskan waktu dengan gadget serta kendala teknis yang dihadapi oleh $50 \%$ keluarga. Kendala reknis ini terkait dengan sinyal, wifi, kuota dan kemampuan dalam kepemilikan gadget. Sehingga dalam pemberian bantuan seperti kuota akan lebih baik jika diberikan juga dukungan kepada siswa yang belum memiliki gadget dan bantuan untuk daerah yang masih terkendala sinyal karena belum ada pemancar.
\end{abstract}

Keywords: pengasuhan; pendampingan; pandemi covid-19; orang tua.

Copyright (c) 2022 Puji Yanti Fauziah, et al.

$\triangle$ Corresponding author:

Email Address : Pujiyantif@uny.ac.id (Bantul, Yogyakarta. Indonesia)

Received 16 September 2021, Accepted 21 December 2021, Published 13 January 2022 


\section{INTRODUCTION}

World health organization (WHO) In 2020 has declared a global COVID-19 pandemic. The Covid-19 pandemic has also affected the order of life, including in Indonesia. In Indonesia, the Covid-19 pandemic has caused the emergence of restricted social movement rules or known as large-scale social restrictions (PSBB) which are implemented in some regions in Indonesia.

The Covid-19 pandemic affects the course of important sectors in the state order, both the economy and education, with the emergence of regulations work from home (WFH) working from home this is done as a hope to prevent community mobility including distance learning (PJJ) or online learning (Shofiyah, et al 2022). The distance learning program (PJJ) is carried out independently in their respective homes. This policy encourages parents to further strengthen their role as the first and foremost educators for their children.

The existence of policies from the government related to maximizing activities at home also further purifies and strengthens the role of the family in the field of education. Parents have an important role in educating children, providing cognitive skills, mental and physical health education, and improving the quality of family psychological health(Mann et al., 2004; Wyatt Kaminski et al., 2008).

The role of parents is re-purified as educators, parental involvement in supervising learning activities, the main learning resource for children, parental authority in providing teaching to children according to the material from the teacher, and carrying out their role as substitute teachers during learning activities from home (Epstein, JL, \& Becker, 2018). The PJJ policy makes parents unprepared to do homework as well as become substitute teachers during PJJ. A simple example of a teacher giving assignments through WhatsApp groups, the Google Classroom application, the Google Meet platform, Google Zoom, and so on to integrate technology in the virtual teaching and learning process (Okmawati, M., \& Tanjak, 2011).

The assignments given by the teacher are according to the subject schedule and lesson hours. Students then work independently at home, then assign this task under teacher monitoring and mentoring, so that children really learn. Furthermore, the teacher coordinates with parents, either through video calls or by sending photos of children's learning activities at home to ensure there is interaction between teachers and parents, with adequate internet support (Purwanto, A., et. al 2020).

The existence of PJJ adds to the duties of parents who are also teachers at home. Parental involvement is a process of parents to mobilize their abilities for the needs of themselves, their children, and the programs implemented by the children (Patmodewo, 2011). Parental care and assistance is an alternative that can be used to increase the collaboration between educators and parents and increase the role of parents. The family as an informal educational institution is protected in Law no. 20 of 2003 concerning the National Education System(Sisdiknas, 2003). The family is the first and foremost educational institution, parental management in providing children's education at home, at school and in the community is the goal of children's academic success (Gutman, LM, \& McLoyd, 2000;Slameto, 2010).

The family has a vital role in preparing children's education so that children can realize their dreams. Family education is a process and lasts throughout the ages, so that everyone acquires values, attitudes, skills and knowledge derived from daily life experiences, environmental influences including the influence of family life, relationships with neighbors, work and play environments, markets, libraries and media. mass (Sudjana, 2004). The existence of the Covid-19 pandemic changes and requires all individuals or groups including every family in the world to be able to adapt to these conditions. Indirectly, the Covid-19 pandemic has become a burden for some families to keep balancing their daily activities from starting to work, nurturing, mentoring, and other activities.

Parenting is considered a natural developmental stage in the human journey (Taubman-Ben-Ari, O., Ben-Yaakov, O., \& Chasson, 2021). Parenting is an important thing for parents to do in the family which is the main task of every parent to their child. Parenting 
plays a role in assisting children during activities at home such as caring for cleanliness, health, education, guiding attitudes and skills of religious and moral values, and other good characters (Kurniati, E., Nur Alfaeni, DK, \& Andriani, 2020). The ability of the family to provide support such as time and attention in meeting the physical, mental and social needs of children who are in the growth stage is certainly related to the process of nurturing and assisting a family or community (Rakhmawati, 2015). Parenting and assisting children during the Covid-19 pandemic can be influenced by the role of parents, which allows the role of parents to expand or increase the burden of their care and assistance.

Family education places a more perfect nature and manifestation than other educational centers, to advance towards intelligence character education (the formation of individual character) and make provisions for social life.(Dewantara, 1961). Intelligence attitude is one form of instilling the basis of religion in children. The atmosphere of family life is the best place for personal education (individual education) and social education (Yulianingsih, Suhanadji, Nugroho, \& Mustakim, 2020).

The family is an ideal place in realizing the function of education in the formation of an individual, cognitive development, and neurocognitive development(Noble et al., 2015). The role of the family cannot be replaced even though the child has studied in formal and nonformal educational institutions. As caregivers and mentoring in the family, laying the foundations of behavior for children, attitudes, behaviors, and habits of parents will always be seen, assessed, and imitated by children (Baumrind, 1978). This parental attitude includes the way parents give rules, rewards, punishments, the way parents show their authority, and the way parents pay attention and respond to their children (Augustin, 2015).

Parents are the ones with the most intense encounters with children, so parental assistance is needed as a coordination between teachers and parents when children learn from home (Epstein, JL, \& Becker, 2018). Parents should teach their children how to solve their own problems (Suyadi, 2010)Some characteristics of online learning include: constructivism, social constructivism, community of learners, virtual classes, and behavioral interactivity, independence, accessibility and enrichment (GTK, 2016).

Some parents consider their involvement in children's education only limited to covering costs, providing infrastructure and various other material needs. In the context of education, parental involvement must cover a wider scope than financing alone. The involvement of parents in educational institutions can be done through various efforts, including as educators, observers of the learning process in the classroom, volunteers, and policy makers in schools. Some of the reasons underlying the importance of parental involvement in education are being able to communicate well to parents about the activities carried out by children. In addition, it also contributes to the achievement of children's developmental tasks, both in cognitive aspects and other developmental aspects (Diadha, 2015).

The results of research from Wardani and Ayriza in 2020 which examined the analysis of parental constraints in accompanying children to study during the pandemic, showed that there were obstacles faced by parents such as lack of understanding of the material, difficulties in growing children's interest in learning, lack of time, as well as emotions. parents such as lack of patience and difficulty operating gadgets as well as the lack of internet service coverage (Wardani, A., \& Ayriza, 2020). The learning system has many challenges that must be mastered by parents, such as learning at home will be flexibly promoted with collaboration between educators, parents, children and institutions which are the key to success in educating and parenting (Mufaziah, E., \& Fauziah, 2020). So from the background explanation above, it will be different regarding what obstacles parents experience in caring for their children during the Covid-19 pandemic. Based on this explanation, the purpose of this study was to look at the problems faced by parents in the city of Yogyakarta in child nurture and learning assistance for children in the family during the covid -19 pandemic. 


\section{METHODOLOGY}

This research is a descriptive qualitative research. This research was conducted in Yogyakarta Province. Figure 1 is the flow of this research.

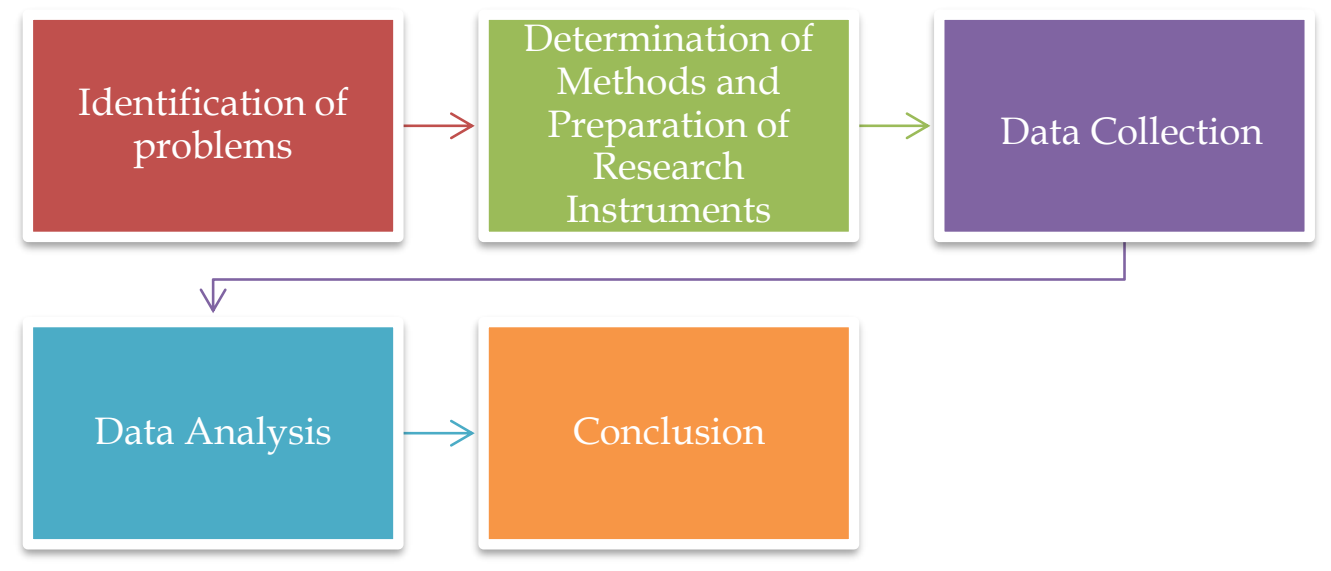

Figure 1. Research Flow

This research uses survey method. The respondents of this study were parents, totaling 78 people.This study uses a closed questionnaire in which answer choices have been provided so that respondents simply put a checklist on the answer choices that are already available in the questionnaire through the Google Form platform. As a poll of respondents related to the situation being studied.The survey results were processed and mapped to see the problems faced by parents in caring for and mentoring children's learning during the Covid 19 pandemic.

\section{RESULTS AND DISCUSSION}

Respondents in this study amounted to 78 parents, $85.9 \%$ of whom were female while $14.1 \%$ were male. With $33.3 \%$ of them having the latest education S1/D4, 33.3\% having the last education high school/equivalent and $11.5 \%$ having the last D3 education, the most domicile coming from Gunungkidul and Klaten districts which is $17.9 \%$. And related to the role of mothers in assisting children in learning, it was found that the role of mothers was $67.9 \%$ more dominant in accompanying children's learning, while the remaining $29.5 \%$ of children's learning process was accompanied by their parents (father and mother).

Parents also spend time studying with their children $43.6 \%$ of parents spend 2 hours a day accompanying their children to study, $26.9 \%$ of parents accompanying their children to study only when there are assignments, $15.4 \%$ of parents spending more than 3 hours a day in accompanying children to study, and $14.1 \%$ of parents spend 3 hours a day accompanying children to learn. Learning assistance is provided by parents and $57.7 \%$ of parents accompany their children to learn to complete school assignments. And as many as $33.3 \%$ of parents feel unskilled in assisting children to learn. The success of the teaching process of children is not only the responsibility of the government or educational institutions, but also the responsibility of the parents. This is the first and most important education for children's success in learning(Gutman, LM, \& McLoyd, 2000;Slameto, 2010 ;Irma, CN, Nisa, K., \& Sururiyah, 2019).

The family is an environment that has a major influence on the growth and education of children (Angus, 2020 ;Khadilkar, H., Ganu, T., \& Seetharam, 2020 ; Andriyani, 2018). Mentoring is very much needed and needed by children in every learning activity carried out at home. The assistance provided has an important role in all aspects of children's development so as to improve the quality of the child's overall development and mentality, as 
well as quality time with parents (Mann et al., 2004;Wyatt Kaminski, et al., 2008; Yulianingsih, W., Suhanadji, S., Nugroho, R., \& Mustakim, 2020).

The impact felt by parents, namely $39.7 \%$ of parents were dizzy because their children did not want to go to school and did not want to learn. As many as $34.6 \%$ of parents make plans during daily routine activities with children, but the daily condition is that children spend more time $47.4 \%$ of children spend more time at home playing games.Learning that is done online and connected to the internet, can make children access anything. The role of parents and adults around children is very necessary, such as supervision of what children open, restrictions on accessing certain features, time period in playing gadgets and so on (Sahriana, 2019). In addition, it is necessary to have sufficient understanding of parents regarding technology, especially gadgets, so that supervision and assistance is consistent. If parents and adults around do not provide assistance to children during online learning, what is feared is that children do things they don't want, such as accessing pornographic sites that can damage the child's brain. Especially at school age, children are easy to imitate negative things (Alia, 2018).

The ability of parents to facilitate children in the form of gadgets is $53.8 \%$ of parents who do not provide gadgets or laptops for children to study and complete tasks, while the remaining $46.2 \%$ of parents provide gadgets or laptops for children to study and complete tasks. Although parents feel various obstacles, but on the positive side, parents feel that $73.1 \%$ of parents feel the benefits of seeing their child's growth and development when their child can study at home, $71.8 \%$ of parents feel that they can be closer to their child when their child can study at home and $38.5 \%$ parents feel that they can re-learn school lessons when their children can study at home. And the main obstacle felt by parents was that $37.2 \%$ of parents had problems spending money when accompanying their children to study at home, the rest experienced problems, including not being able to accompany children to study, because they had homework, did not have a cellphone or laptop and so on. And another obstacle is that $51.3 \%$ of parents have difficulty with internet quotas when accompanying children to study at home, while the remaining $48.7 \%$ of parents do not experience internet quota difficulties.

The COVID-19 pandemic has made some people quit their jobs, thus making parents earn more money. Because parents are focused on looking for economic strengthening, the assistance for children is not optimal. Increased expenses due to having to buy quotas for smooth online learning, inadequate facilities in carrying out online learning, so that there are parents who take turns using the facilities with their children and there are also those who increase the budget to buy online learning needs such as androids, laptops and so on, there are also problems regarding children who prefer to play rather than study because the school atmosphere does not feel at home, and parents' understanding of the operation of technology is still minimal.(Dewi, 2015; Satrianingrum \& Prasetyo, 2020). So it is clear that the role of parents in guiding and motivating their children to keep the spirit in doing something at home is important. Basically, if it is encouraged by parents and other relatives, the child will have the motivation to do something (Yulianti, 2014). Motivation is a series of efforts to create certain conditions to stimulate someone to do something. These roles are brought up by parents as a way of parenting (Harahap, 2018).

Based on the results of the research conducted, it can be concluded that one of the obstacles in parenting during the Pandemic was when accompanying PJJ, another obstacle felt was that parents did not feel they had the ability to assist children in learning, were quick to emotion, quotas and networks. One of the obstacles when PJJ is children feel bored staying at home, while the majority of activities carried out by parents are gardening and cooking together. In addition, children are also given the opportunity to play, and one of the most popular games is playing games. The time needed by PJJ children is two hours per day.

Regarding the limited knowledge and understanding of teachers and parents about home schooling, sometimes they release the basic rules of home schooling, which include: (1) learning based on the needs of students, meaning that students are free to learn various things 
they want, in the way they want. , and in the desired place based on the reasons from within the learner; so that schools and parents in this case must give flexibility to children to appreciate the interests, moods and interests of children in learning the subject matter. (2) education as an interaction between parents as facilitators and children as students; The problem that arises is that current conditions force parents who do not have the competence to teach to be faced with the demands of children studying at home, so that the problem arises, namely "verbal violence" which is actually carried out by parents because of the limitations of parents in teaching children. and (3) being independent in the process of providing education.

The difficulty of parents in providing learning assistance, it can be identified early that the limited ability of parents in parenting in disciplining children and the perception of parents who do not have the ability to accompany children at home. Even though parenting is not an easy thing, it requires dedication, excellent service for 24 hours and even qualified competence as a parent. For some parents, childcare is a very important investment to develop human capital in children. Parental education affects parenting patterns and the use of time with children. Mothers with higher education spend more effective and quality time with their children than mothers with secondary or less education..

Ki Hajar Dewantara explained that the family is a collection of individuals who have a sense of selfless devotion, for the benefit of all individuals who take shelter in it. Ki Hajar Dewantara views the importance of the family as one of the centers of children's education and has a meaningful life meaning for humans both as individuals and as a group of people. Ki Hajar also stated that the family realm for everyone (children) is the realm of initial education. For the first time, parents (father and mother) serve as guides (teachers), as teachers, as educators, mentors and as primary educators for children. With the COVID-19 condition, parents also have an additional role, namely as a medium of transfer of knowledge for children.

The pandemic has brought awareness to the importance of the role of the family, especially mothers and fathers who have extraordinary roles and functions in nurturing, education, and mentoring. This is in accordance with Meece's explanation that the family factor has been proven to have an important position for children's education through the mother's style in disciplining children, the response given to the child, the involvement of the child with the mother, the availability of learning materials, organizing the family environment, and the opportunity for children to get a stimulus in learning. everyday life. The ability of parents in creating a warm, supportive, responsive family environment, encouraging exploration, facilitating learning and playing materials, stimulating children's curiosity makes a positive contribution in accelerating children's intellectual development.

\section{CONCLUSION}

The Covid-19 pandemic has made parents experience various obstacles related to parenting and assisting children in learning, ranging from the inability of parents to explain school material, disciplining children, spending too much time with gadgets and technical obstacles faced by $50 \%$ of families related to signals, wifi, quotas. and the limited ability of the community to own gadgets. So that in addition to providing quota assistance, it would be better if it was given support for students who have limitations in possession of gadgets, or areas where infrastructure is constrained by not having a signal because there is no transmitter.

\section{ACKNOWLEDGEMENTS}

Thanks to DRPM DIKTI and UNY who have facilitated researchers so that this article can be published, partners who are willing to participate in research and the Obsession Journal team who have published this article so that it can be read by the public. Hopefully this article is useful both theoretically and practically. 


\section{REFERENCES}

Agustin, NM (2015). Early Childhood Parenting Patterns. Surabaya: Unesa University Press. Unesa University Press.

Alia, T. (2018). Parental Assistance in Early Childhood in the Use of Digital Technology. A. Journal of Language, Literature, Culture and Education, 14(1), 65-78. https:// doi.org/10.19166/pji.v14i1.639

Andriyani, IN (2018). Children's Education in Families in the Digital Age. FIKROTUNA, 7(1), 789-802. https://doi.org/10.32806/if.v7i1.3184

Angus, DC (2020). Optimizing the Trade-off between Learning and Doing in a Pandemic. JAMA - Journal of the American Medical Association. https:// doi.org/10.1001/jama.2020.4984

Baumrind, D. (1978). Parental disciplinary patterns and social competence in children. Youth \& Society, 9(3), 239-267. https:// doi.org/10.1177/0044118X7800900302

Dewantara, KH (1961). Educational Sciences. Yogyakarta: Student Park.

Dewi, R. (2015). Products of Malay Culture Close to Extinction. Journal of Education STKIPPGRI Lubuklinggau. Journal of Education. Volume No. 15 of 2015.

Diadha, R. (2015). Parental involvement in early childhood education in kindergarten. Educentric, 2(1), 61. Https:/ / Doi.Org/10.17509/Educentric.V2i1.161.

Epstein, JL, \& Becker, HJ (2018). Teachers' reported practices of parent involvement: Problems and possibilities. School, Family, and Community Partnerships, Student Economy Edition: Preparing Educators and Improving Schools, 83(2), 115-128. https:// doi.org/10.4324/9780429493133

Fauziah, AN and PY (2022). Parenting Disorder in the Era of the Covid-19 Pandemic: Impact, 6(3), 1461-1471. https:/ / doi.org/10.31004/obsesi.v6i3.1769

GTK, D. (2016). Technical Instructions for the Improvement of Online Mode Learning Teacher Program.

Gutman, LM, \& McLoyd, VC (2000). Parents' management of their children's education within the home, at school, and in the community: An examination of african-american families living in poverty. Urban Review, 32(1), 1-24. https:// doi.org/10.1023/A:1005112300726

Irma, CN, Nisa, K., \& Sururiyah, SK (2019). Parental Involvement in Early Childhood Education at TK Masyithoh 1 Purworejo. Obsession Journal: Journal of Early Childhood Education, 3(1), 214. https:// doi.org/10.31004/obsesi.v3i1.152

Khadilkar, H., Ganu, T., \& Seetharam, DP (2020). Optimizing Lockdown Policies for Epidemic Control using Reinforcement Learning. ArXiv. Https:/ / Doi.Org/10.1007/S41403-02000129-3.

https:// doi.org/10.1007/s41403-020-00129-3

Kurniati, E., Nur Alfaeni, DK, \& Andriani, F. (2020). Analysis of the Role of Parents in Accompanying Children during the Covid-19 Pandemic J. Urnal Obsession: Journal of Early Childhood Education, 5(1), 241. https://doi.org/10.31004/obsesi.v5i1.541

Mann, M., Hosman, CMH, Schaalma, HP, \& De Vries, NK (2004). Self-esteem in a broadspectrum approach for mental health promotion. Health Education Research, 19(4), 357-372. https://doi.org/10.1093/her/cyg041

Mufaziah, E., \& Fauziah, P. (2020). Obstacles of Parents in Educating Early Childhood During the Covid 19 Pandemic. Obsession Journal: Journal of Early Childhood Education, 5(2), 1045-1051. https:// doi.org/10.31004/obsesi.v5i2.746

National Education System. (2003). Law of the Republic of Indonesia concerning the National Education System Number 20 of 2003.

Noble, KG, Houston, SM, Brito, NH, Bartsch, H., Kan, E., Kuperman, JM, A., \& N., Amaral, DG, Bloss, CS, Libiger, O., Schork, NJ, Murray, SS, Casey, BJ, Chang, L., Ernst, TM, Frazier, JA, Gruen, JR, Kennedy, DN, Van Zijl, P., ... Sowell, ER (2015). Family income, 
parental education and brain structure in children and adolescents. Nature Neuroscience, 18(5), 773-778. https:// doi.org/10.1038/nn.3983

Okmawati, M., \& Tanjak, D. (2011). Teaching the use of google classroom during the pandemic. $9(2)$. Journal of English Language. https://doi.org/10.24036/jelt.v9i2.109293

Patmodewo, S. (2011). Preschool Education. Bandung: Rineka Cipta.

Please, FIN (2018). The Effect of Parenting Program Results and Parenting Patterns on Increasing Early Childhood Learning Motivation. Al-Muaddib: Journal of Social \& Islamic Sciences, 3(1), 1-15. https:// doi.org/10.31604/muaddib.v1i1.367

Purwanto, A., Asbari, M., Fahlevi, M., Mufid, A., Agistiawati, E., Cahyono, Y., \& Suryani, P. (2020). Impact of Work From Home (WFH) on Indonesian Teachers Performance During the Covid-19 Pandemic: An Exploratory Study. International Journal of Advanced Science and Technology, 29(5), 6235-6244.

Rakhmawati, I. (2015). The Role of the Family in Parenting. Journal of Islamic Counseling Guidance, 6(1), 1-18. Https://Doi.Org/10.21043/Kr.V6i1.1037.

Sahriana, N. (2019). The importance of parental dialogical assistance in the use of gadgets in early childhood. Smart Early Childhood Journal, 2(1), 60. https:// doi.org/10.36709/jspaud.v2i1.5922

Satrianingrum, AP, \& P. . (2020). Teacher Perceptions of the Impact of the Covid-19 Pandemic on the Implementation of Online Learning in PAUD. Obsession Journal: Journal of Early Childhood Education, 5(1), 633. https://doi.org/10.31004/obsesi.v5i1.574

Slamet. (2010). Learning and the Factors That Affect It. Revised Edition. Jakarta: PT. Rineka Cipta.

Suyadi. (2010). PAUD Learning Psychology. Pedagogy.

Taubman-Ben-Ari, O., Ben-Yaakov, O., \& Chasson, M. (2021). Parenting stress among new parents before and during the COVID-19 pandemic. Child Abuse \& Neglect, 117(April), 105080. https:// doi.org/10.1016/j.chiabu.2021.105080

Wardani, A., \& Ayriza, Y. (2020). Analysis of Parental Obstacles in Accompanying Children Studying at Home During the Covid-19 Pandemic Obsession Journal: Journal of Early Childhood Education, 5(1), 772. https://doi.org/10.31004/obsesi.v5i1.705

Wyatt Kaminski, J., Valle, LA, Filene, JH, \& Boyle, CL (2008). A meta-analytic review of components associated with parent training program effectiveness. Journal of Abnormal Child Psychology, 36(4), 567-589. https://doi.org/10.1007/s10802-007$\underline{9201-9}$

Yulianingsih, W., Suhanadji, S., Nugroho, R., \& Mustakim, M. (2020). Parental Involvement in Children's Learning Assistance during the Covid-19 Pandemic Period. Journal. Obsession: Journal of Early Childhood Education, 5(2), 1138-1150. https://doi.org/10.31004/obsesi.v5i2.740

Yulianingsih, W., Suhanadji, S., Nugroho, R., \& Mustakim, M. (2020). Parents' Involvement in Children's Learning Assistance during the Covid-19 Pandemic Period. Obsession Journal: Journal of Early Childhood Education, 5(2), 1138-1150. https://doi.org/10.31004/obsesi.v5i2.740

Yulianti, TR (2014). The Role of Parents in Developing Early Childhood Creativity (Case Study at the Melati PAUD 13 Post, Padasuka Village, Central Cimahi District). Journal of EMPOWERMENT, 4(2252), 11-24. 